\title{
TOP TEN SMART CITIES IN THE WORLD. WHAT DO THEY HAVE IN COMMON AND HOW CAN EASTERN EUROPEAN CITIES USE THAT?
}

\author{
Catalin Vrabie ${ }^{1}$ and Andreea-Maria Tirziu ${ }^{2}$
}

\begin{abstract}
Although the smart city concept is rather old, the literature fails in defining it properly - however, most, if not all, scholars are sharing the same idea: a main characteristic of smart cities is the use of information and communications technology in all aspects of city life. All of the actors actively involved in building a smart city (and we mention here academia, IT professionals and municipalities' officials) are trying to build up a common definition, but until now they were not successful. However, many smart city rankings have been made by different researchers from various fields of activity. In this paper we will use the indicators that were found as being common in some of those rakings (made by prestigious institutions) in order to find the most common features of a smart city. Our intention is to suggest a model of a smart city based on the existing international experiences and to offer it for study to municipalities' officials in Romania and other countries in the region. The main research method will be a quantitative one (based, as we have already mentioned, on the common indicators used in building international rakings), but we will use a qualitative one as well in order to highlight, as study cases, few of the most notorious examples of smart cities.
\end{abstract}

\section{Introduction}

We often ask our collaborators to seek to identify the problems their city is facing, problems that, given the complexity of a locality, can be individualized and solved, partially at least, by using modern technologies specific to the information era we are living in. We want them to write down every idea that appears so that, in the design phase of a smart city, we can appeal to those ideas by also investigating the infrastructure, data and technologies already in place.

IESE insight business knowledge portal [10] - IESE is consistently ranked among the world's very best business schools [24] alongside the Business Insider portal [3] - No. 1 business publication in the United States [25], have been chosen as milestones in our analysis due to the popularity among citizens of the information disseminated through them, offer a top of the smartest cities in the world as well as some indications on how to get to that top.

Companies developing smart solutions having as a starting point the service providers, are often surprised by the fact that their products or services are not popular among government agents or citizens (unless the law requires it - such as the electronic public procurement system in Romania, SEAP/SICAP [17], but in this case the desire of users to work with the system is uncertain).

\footnotetext{
${ }^{1}$ Lecturer, PhD., The National University of Political Studies and Public Administration (SNSPA) - Faculty of Public Administration, Bucharest, Romania. Email: cataloi@yahoo.com

${ }^{2} \mathrm{PhD}$. candidate, The National University of Political Studies and Public Administration (SNSPA) - Faculty of Public Administration, Bucharest, Romania. Email: tirziu.andreea@yahoo.com
} 
Developers often fail when they try to understand the real needs of users/citizens; therefore we believe that they should be involved in the strategic planning process in order to achieve successful smart solutions. We will further see what were the basic ingredients in developing the smartest cities in the world.

\section{Overview of the smartest cities in the world (2017)}

\begin{tabular}{|c|c|c|c|}
\hline Rank & City, Country & Observations & Key elements \\
\hline 1 & $\begin{array}{l}\text { Copenhagen, } \\
\text { Denmark }\end{array}$ & $\begin{array}{l}\text { Boasts a healthy startup ecosystem, a large } \\
\text { number of Wi-Fi hotspots, and a relatively } \\
\text { low amount of traffic congestion. The city is } \\
\text { also investing in clean energy, with a goal of } \\
\text { being } 100 \% \text { carbon-neutral by } 2025 \text {. }\end{array}$ & $\begin{array}{l}\text { technology, } \\
\text { environment }\end{array}$ \\
\hline 2 & Singapore & $\begin{array}{l}\text { Features one of the most cost-efficient public } \\
\text { transport networks in the world [18]. }\end{array}$ & $\begin{array}{l}\text { mobility and } \\
\text { transportation }\end{array}$ \\
\hline 3 & $\begin{array}{l}\text { Stockholm, } \\
\text { Sweden }\end{array}$ & $\begin{array}{l}\text { A large portion of city buses and trains run on } \\
\text { clean fuels. Renewable power sources } \\
\text { account for } 52 \% \text { of Swedish energy } \\
\text { production. }\end{array}$ & $\begin{array}{l}\text { environment, } \\
\text { mobility and } \\
\text { transportation }\end{array}$ \\
\hline 4 & $\begin{array}{l}\text { Zurich, } \\
\text { Switzerland }\end{array}$ & $\begin{array}{l}\text { Has an urban plan that includes a high } \\
\text { percentage of green space. }\end{array}$ & environment \\
\hline 5 & $\begin{array}{l}\text { Boston, } \\
\text { US }\end{array}$ & $\begin{array}{l}\text { The metro area around it has several colleges, } \\
\text { including MIT and Harvard, which lead the } \\
2018 \text { World University Rankings. }\end{array}$ & edu \\
\hline 6 & $\begin{array}{l}\text { Tokyo, } \\
\text { Japan }\end{array}$ & $\begin{array}{l}\text { The rail system handles over } 100 \text { train lines } \\
\text { and } 14 \text { billion passengers per year. }\end{array}$ & $\begin{array}{l}\text { mobility and } \\
\text { transportation }\end{array}$ \\
\hline 7 & $\begin{array}{l}\text { San Francisco, } \\
\text { US }\end{array}$ & Has a high number of startups. & $\begin{array}{l}\text { economy, human } \\
\text { capital }\end{array}$ \\
\hline 8 & $\begin{array}{l}\text { Amsterdam, } \\
\text { Netherlands }\end{array}$ & $\begin{array}{l}\text { Has well-established startup communities, } \\
\text { along with successful incubator programs like } \\
\text { StartupDelta [19] and StartupAmsterdam [9]. }\end{array}$ & $\begin{array}{l}\text { economy, human } \\
\text { capital }\end{array}$ \\
\hline 9 & $\begin{array}{l}\text { Geneva, } \\
\text { Switzerland }\end{array}$ & $\begin{array}{l}\text { Has prioritized energy-efficient infrastructure } \\
\text { in its buildings and public transit. By } 2020 \text {, } \\
\text { the city plans to reduce its carbon dioxide } \\
\text { emissions } 21 \% \text { below } 2005 \text { levels. }\end{array}$ & environment \\
\hline 10 & $\begin{array}{l}\text { Melbourne, } \\
\text { Australia }\end{array}$ & $\begin{array}{l}\text { Received a perfect score on its } 4 \mathrm{G} \\
\text { connectivity. }\end{array}$ & technology \\
\hline
\end{tabular}

Table 1: Top ten smart cities in the world according to Business Insider [3]

Counting the key elements in Table 1, it is easy to observe that Business Insider considers that a smart city should have, as the most important features, the following elements:

- Environment (4) - clean energy and the presence of green spaces are among the most important aspects;

- Mobility and transportation (3) - very closely related to the environment feature; it mostly refers to the municipality's ability to build a green and efficient transportation system for its citizens; 
- Technology (2) - it mostly refers to connectivity either by Wi-Fi or 4G;

- Economy (2) - the presence of a large number of startups shows the openness of the city's officials to the future;

- Human capital (2) and education (1) - it might not be visible from the table above, but all the cities mentioned are large university centers, aspect that we consider very important for the smart cities' development due to the research centers that usually operate within the universities.

\begin{tabular}{|c|c|c|c|}
\hline Rank & City, Country & Observations & Key elements \\
\hline 1 & $\begin{array}{l}\text { New York, } \\
\text { US }\end{array}$ & $\begin{array}{l}\text { Important economic center, very well } \\
\text { developed in terms of technology (second } \\
\text { place on the top for this dimension). }\end{array}$ & $\begin{array}{l}\text { economy, } \\
\text { technology }\end{array}$ \\
\hline 2 & $\begin{array}{l}\text { London, } \\
\text { UK }\end{array}$ & $\begin{array}{l}\text { Best mobility and transportation and the use } \\
\text { of human capital }\end{array}$ & $\begin{array}{l}\text { mobility and } \\
\text { transportation, } \\
\text { human capital }\end{array}$ \\
\hline 3 & $\begin{array}{l}\text { Paris, } \\
\text { France }\end{array}$ & The world's most popular tourist destination & tourism \\
\hline 4 & $\begin{array}{l}\text { San Francisco, } \\
\text { US }\end{array}$ & Best economy and use of human capital & $\begin{array}{l}\text { economy, human } \\
\text { capital }\end{array}$ \\
\hline 5 & $\begin{array}{l}\text { Boston, } \\
\text { US }\end{array}$ & Human capital and governance & $\begin{array}{l}\text { human capital, } \\
\text { governance }\end{array}$ \\
\hline 6 & $\begin{array}{l}\text { Amsterdam, } \\
\text { Netherlands }\end{array}$ & Urban planning and technology & $\begin{array}{l}\text { urban planning, } \\
\text { technology }\end{array}$ \\
\hline 7 & $\begin{array}{l}\text { Chicago, } \\
\text { US }\end{array}$ & Governance, economy and human capital & $\begin{array}{l}\text { governance, } \\
\text { economy, human } \\
\text { capital }\end{array}$ \\
\hline 8 & $\begin{array}{l}\text { Seoul, } \\
\text { South Korea }\end{array}$ & $\begin{array}{l}\text { Best mobility and transportation and the use } \\
\text { of technology }\end{array}$ & $\begin{array}{l}\text { mobility and } \\
\text { transportation, } \\
\text { technology }\end{array}$ \\
\hline 9 & $\begin{array}{l}\text { Geneva, } \\
\text { Switzerland }\end{array}$ & Best public management & $\begin{array}{l}\text { public } \\
\text { management }\end{array}$ \\
\hline 10 & $\begin{array}{l}\text { Sydney, } \\
\text { Australia }\end{array}$ & $\begin{array}{l}\text { Technology and to some extent public } \\
\text { management }\end{array}$ & $\begin{array}{l}\text { technology, } \\
\text { public } \\
\text { management }\end{array}$ \\
\hline
\end{tabular}

Table 2: Top ten smart cities in the world according to IESE Business School [10]

Despite the fact that only few cities are in both classifications in top ten smart cities (only San Francisco, Boston, Amsterdam and Geneva), they share the same approaches, and those are:

- Human capital (4) - being one of the most important assets, closely linked to education, it is definitely a key ingredient for building a smart city;

- Technology (4) - it mostly refers to the use of mobile apps that make citizens' life more comfortable (parking solutions, traffic congestions, incidents reporting systems etc.);

- Economy (3) and tourism (1) - being an important economic center in the country or region, these are important aspects for the smart cities' development because the public sector and the private one are working together to implement new solutions; 
- Governance (2) and public management (2) - show the city's official strategic views on the future;

- Mobility and transportation (2) and urban planning (1) - as well as in the Business Insider case, IESE Business School refers to the municipality's ability to build a green and efficient transportation system.

For both tables we have taken into consideration the rakings that covers all dimensions (as in the fourth column of each table - Key elements) of urban life.

\section{Best international case studies}

Studying the list of smart cities in the world on both the above mentioned publications, along with their key features, we discovered interesting study cases that we consider as being important to be presented in this section of the paper mostly because they offer collaborative instruments for developing the smart cities concept - one of Romania initial priority, mostly in its commitment to assuring post-communism freedom-of-speech era, was establishing dialog frameworks [27]; therefore, the authors consider the first three international case studies as being collaborativemodels-to-follow by Romanian municipalities. The next ones are examples-to-be-followed due the social innovation instruments they emphasize [26].

Reykjavík, Island, is not on the top ten lists. However it developed one of the most interactive platforms between the municipality and the citizens. Better Reykjavík offers citizens the opportunity to work with Reykjavík city hall. By accessing online content, they can propose, debate and vote ideas for improving city life. The best ten or fifteen of these are added to the local public administration's agenda every month, and the general city hall council is committed to processing and responding to everyone, while creating a dialogue between citizens and mayors, this being a way of elaborating local public policies. Starting in 2011 - the year of launching the platform, and until the time of drafting this paper, over a thousand ideas have been discussed by the general council of Reykjavík, of which several hundred have been accepted. To be noticed in this case is the civic engagement of the Icelandic capital's inhabitants: of the approximately 120,000 inhabitants of the city, more than 70,000 have participated in this process since the platform was launched, managing to direct over 18 million EURO towards putting their ideas into practice [4]. 


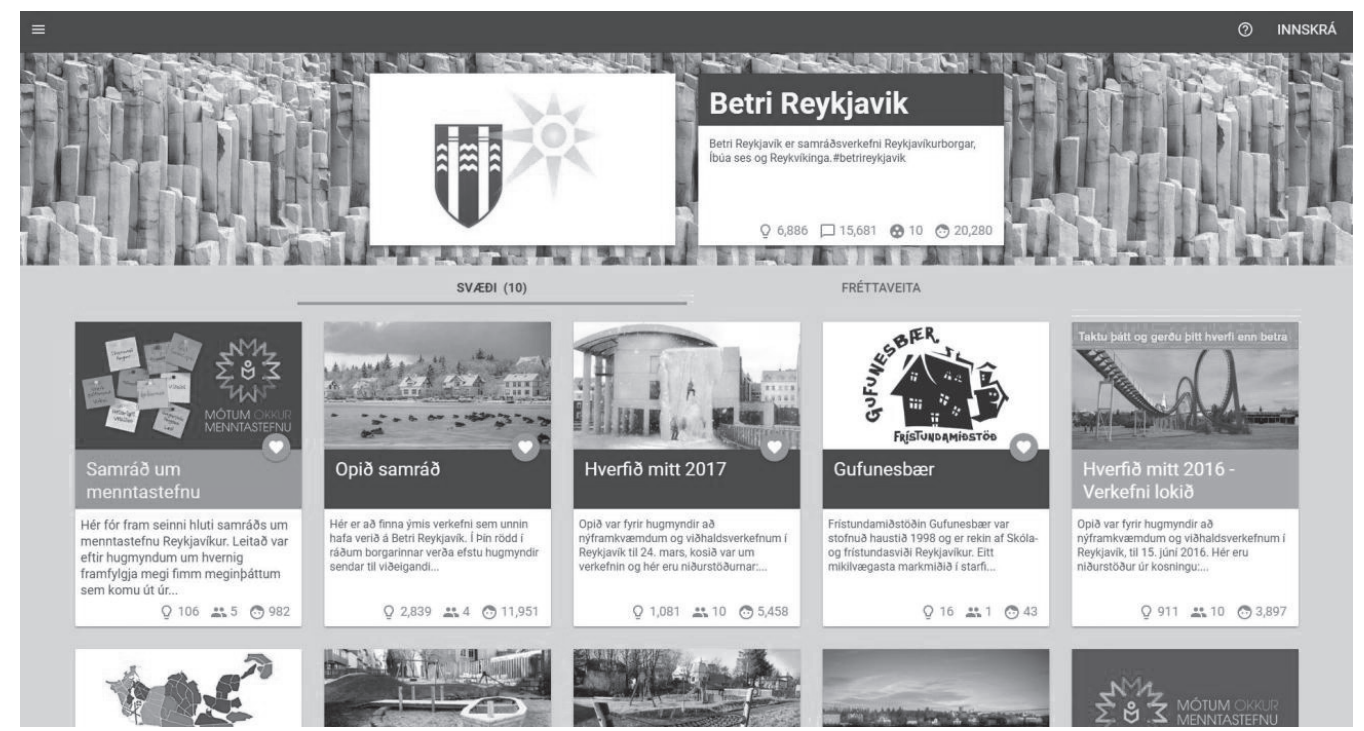

Figure 1: Better Reykjavík [4]

An example for Bangalore city, India, is the NextBengaluru platform [15] which was created independently of the city leaders by a nonprofit organization, MOD Institute [13], and aims to involve citizens in urban planning. It is a place where locals can express their ideas and requirements in accordance with the needs of the city, discuss its future, and collaborate for aligning to a common vision. From the end of 2014 to the time this article was written, the platform connected online and offline locals and managed to collect 454 ideas. At the moment, the MOD Institute tries to persuade the mayors to adopt those ideas at least partially [14].

Milton Keynes, a city in the South East England region, UK, made in 2015, as part of the MK:Smart project [12], Our MK platform [16]. Citizens are encouraged to send ideas that influence the community and help shape a beautiful future for the city. They, therefore, have the possibility to innovate, collaborate, share ideas, by building projects and thus changing their community. In addition, as a bonus for civic engagement, a $£ 5,000$ prize was set up for groups of citizens who have innovative ideas, with an important technological component, ideas that could have a strong impact on Milton Keynes city. Despite the viability of the project and the prize, the civic commitment of the inhabitants was not the one expected - only thirteen project ideas have been submitted [16]. However, we have presented the project because we find it interesting and maybe in this manner, the British example will be taken over and applied to an environment more active from this point of view.

The capital of Finland, Helsinki, promises to transform, by 2025, the current public transport system into a mobility-on-demand one [5]. The goal is to provide residents with a choice of cheap, flexible and coordinated options to compete with the use of personal vehicles. Officials want mobile applications specially developed for this purpose to work both as assistants in planning a trip and as payment platforms for those trips, thus enabling residents to be more efficient with their time and financial resources - users will set a starting point and a destination (similar to the Uber system [22]) as well as transport means preferences, and the application will return a plan that can combine the use of autonomous cars, buses, trains, ferries and even bicycles [21]. 
Bicycle riding - a very popular means of transport in Western Europe, as well as walking, can also be helped by technology. Beat the Street app, developed by Intelligent Health, aims to transform the city into a game where residents can earn points based on the number of steps they take, their time spent on a bicycle or running. Each user has an RFID (Radio-Frequency Identification) card with the help of which he/she identifies himself/herself in passing by beat boxes placed all over the city. From the moment in which the project was launched (2016) until now, developers boast a total of 810,710 users [1].

CycleEye app, a collision avoidance system developed by Fusion Processing, aims to alert drivers of buses, coaches and cargo carriers regarding the existence of a bicyclist in the proximity of their vehicle, thus helping to avoid an accident. The technology is based on camcorders placed outside of large-sized cars, cycling sensitive cameras - in other words, it identifies the bicyclist, with great accuracy, from the rest of the traffic participants [6].
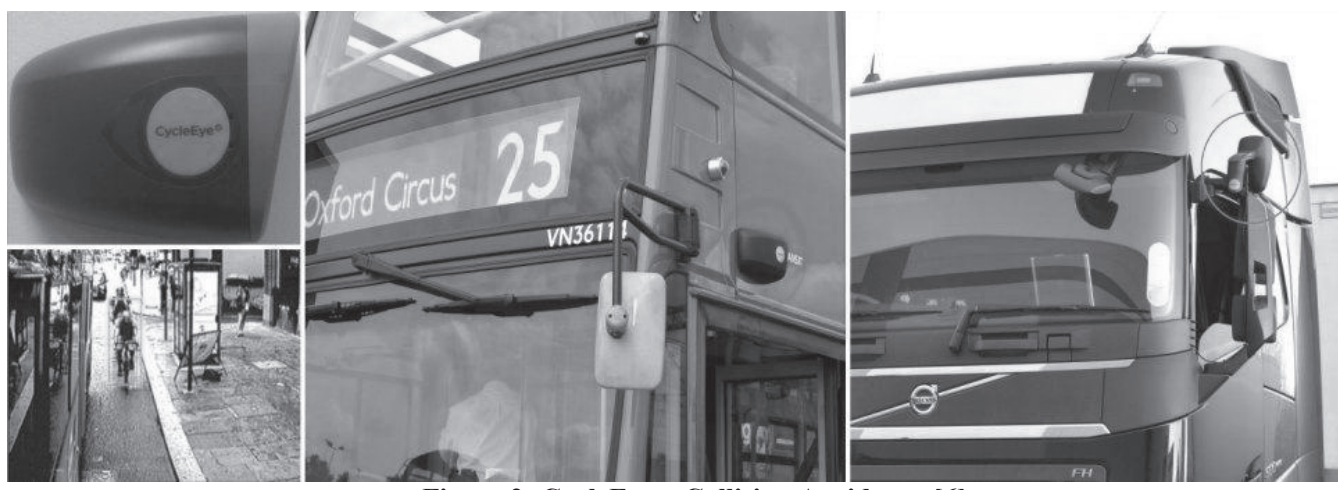

Figure 2: CycleEye - Collision Avoidance [6]

Fusion Processing also develops applications for autonomous machines: CAVstar [7] autonomous vehicle sensing and control system, as well as for traffic sensors: TrafficTrak [8]. Although independent, these applications can very well work together to streamline passenger transport.

\section{Romania best cases}

City of Brasov built up a Business Intelligence Reporting system. It was developed in order to bring together, under the same screen, all the data from every partner, contractor and sub-contractor who reports to the city hall. All this information flow is possible by an easy-to-use Graphical User Interface which allows all the actors to input data effortlessly and with accuracy [2]. 


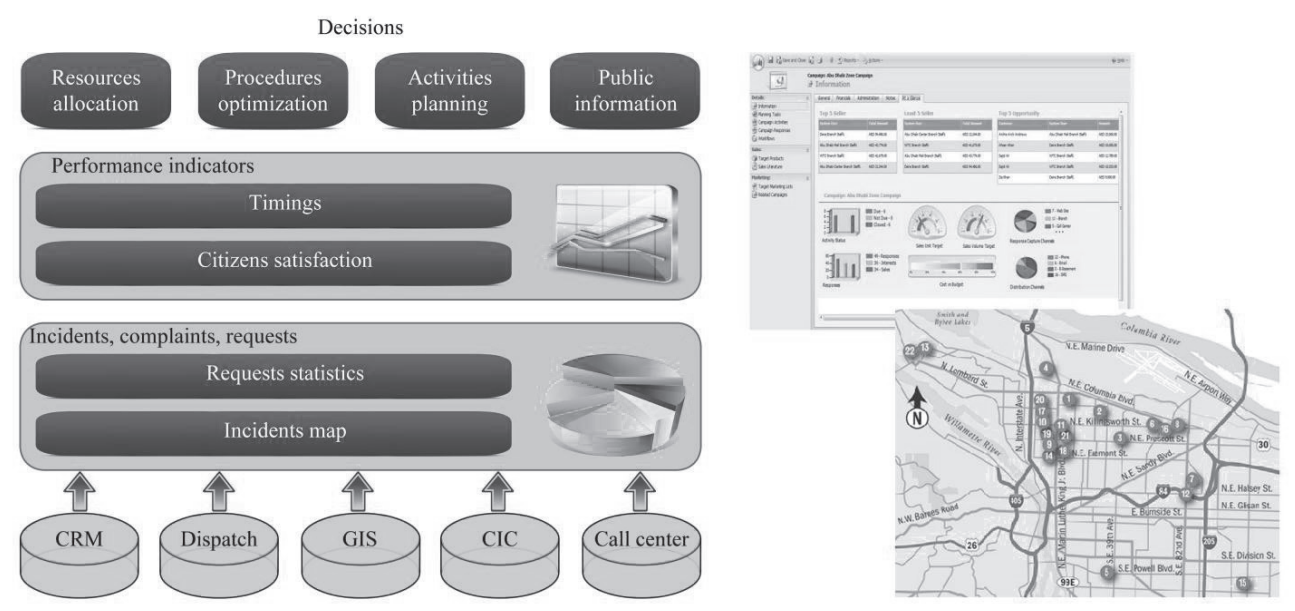

Figure 3: Business Intelligence Reporting system [2]

This site is connected to the following systems:

- Municipality video surveillance;

- Public lightning services;

- Semaphore management system along with data from specific software applications used for traffic control and management;

- The geographic subsystem - Geoportal;

- E-documents system.

Constanta municipality together with Telekom successfully tested two major smart cities solutions. The first one is for the street lightning: a large number of LED bulbs were installed, with reduced consumption and automatic dimming according to some predefined scenarios. Moreover, all of them are remotely controlled by the operators. The second smart solution is related to the parking issue. As a pilot project in Constanta, there are 50 parking lots that are operated by a single control panel. The user interface of the portal is also available as a mobile app and the drivers might get a notification whenever they are near a free parking lot. The intention is to size scale the project for the entire city [20].

\section{Conclusions}

Clearly, for a city to be smart there are no specific recipe and definitely the city officials should understand very well the city's demands. However, few things should be taken into consideration as key ingredients and those are: education, technology, mobility, environment and more, as shown in Table 1 and Table 2.

If we are to look at the Romanian best cases - in this article there were presented only two, but of course there are more, we will see that municipalities are now focusing mostly on the technology 
(and mobility) features, not taking very seriously into account the education and environment features that were found so often in our top ten smart cities of the world.

We strongly believe that Romanian cities today (and maybe not only Romanian) tend to be more outsmarted than smart [11] therefore we suggest to focus more on the real needs of the citizens and the city overall.

Moreover, a city can be considered smart if its citizens are smart. Hence, we consider that it is important for citizens to gain access to the specific education feature needed in every smart city. Individuals should receive a proper training [23] regarding what a smart city is, how they can adapt to living in such a city and how they can get involved in the process of its development and continuity. In this case and not only, their willingness to learn is a key element because if people do not want to be a part of the information era and do not want to adapt to this new way of living, then the whole process of developing a smart city will be affected as for the many individuals are oriented in this direction, the better and easier the path to success is.

All in all we consider that a model-to-be-followed by Romanian municipalities should start from collaboration and education aiming to find the most suitable technical solution, for the local environment, that should be implemented.

\section{References}

[1] BEAT THE STREET, https://www.beatthestreet.me/UserPortal/Default, accessed on 12.12.2017.

[2] BRASOV CITY HALL, http://www.brasovcity.ro/, accessed on 13.12.2017.

[3] BUSINESS INSIDER, These 10 cities are the most prepared for the future, http://www.businessinsider.com/smart-cities-ranking-easypark-group-2017-11/\#10melbourne-australia-received-a-perfect-score-on-its-4g-connectivity-1, accessed on 11.12.2017 (2017).

[4] CITIZENS FOUNDATION, https://citizens.is/portfolio_page/better_reykjavik/, accessed on 11.12.2017.

[5] ENERGYCITIES, http://www.energie-cites.eu/db/Helsinki_Pocacito_Mobility-on-demand_ 2015_en.pdf, accessed on 12.12.2017 (2015).

[6] FUSION PROCESSING, http://www.fusionproc.com/products/, accessed on 12.12.2017.

[7] FUSION PROCESSING, http://www.fusionproc.com/cavstartm/, accessed on 12.12.2017.

[8] FUSION PROCESSING, http://www.fusionproc.com/trafficmonitor/, accessed on 12.12.2017.

[9] IAMSTERDAM, https://www.iamsterdam.com/en/business/startupamsterdam/we-are-startup amsterdam/what-is-startupamsterdam, accessed on 11.12.2017. 
[10] IESE BUSINESS SCHOOL, IESE Cities in Motion Index 2017, http://www.iese.edu/research/pdfs/ST-0442-E.pdf, accessed on 11.12.2017 (2017).

[11] KISILOWSKI, M., CEE Cities: Smart or Outsmarted?, Central European University, paper presented at the Smart Cities Conference, $5^{\text {th }}$ edition, December 7, 2017, SNSPA, Bucharest, Romania (2017).

[12] MK:SMART, http://www.mksmart.org/, accessed on 11.12.2017.

[13] MOD INSTITUTE, http://www.mod.org.in/, accessed on 11.12.2017.

[14] MOD INSTITUTE, About NextBengaluru, http://www.mod.org.in/mod/wp-content/uploads /2015/03/MOD-Nextbengaluru-.-PEOPLES-VISION-ON-FUTURE-SHANTHINAGARBooklet-_-web.pdf, accessed 11.12.2017.

[15] NEXTBENGALURU, http://gatishil.nextbangalore.com/\#about, accessed on 11.12.2017.

[16] OUR MK, https://ourmk.org/, accessed on 11.12.2017.

[17] ROMANIAN DIGITAL AGENDA AGENCY, Public procurement reform - SICAP platform, https://www.aadr.ro/reforma-\%C3\%AEn-domeniul-achizitiilor-publice-platforma-sicap_148 _- 0. html, accessed on 11.12.2017.

[18] SIEMENS, Singapore Climate Close-Up, https://www.siemens.com/press/pool/de/events/ 2014/infrastructure-cities/2014-06-CCLA/singapore-climate-close-up.pdf, accessed on 11.12.2017 (2014).

[19] STARTUPDELTA, https://www.startupdelta.org/, accessed on 11.12.2017.

[20] TELEKOM, https://www.telekom.ro/despre-noi/media/news/telekom-lanseaz-un-nou-proiectpilot-de-tip-smart-city-n-constana/article113312, accessed on 13.12.2017.

[21] THE GUARDIAN, https://www.theguardian.com/cities/2014/jul/10/helsinki-shared-publictransport-plan-car-ownership-pointless, accessed on 12.12.2017 (2014).

[22] UBER, https:/help.uber.com/h/738d1ff7-5fe0-4383-b34c-4a2480efd71e, accessed on 11.12.2017.

[23] VRABIE, C., Elements of IT for the public administration, vol. 2, 2nd Edition, Pro Universitaria Publishing House, Bucharest (2014).

[24] IESE BUSINESS SCHOOL, https://www.iese.edu/en/about-iese/rankings-accreditations/ rankings accessed on 25.02.2018 (2018)

[25] BUSINESS INSIDER, http://www.businessinsider.com/business-insider-traffic-2014-11 accessed on 25.02.2018 (2014) 
[26] TÎRZIU, A.M., Social innovation labs - instruments of social change, Proceedings of the "Smart Cities" Conference (SCC), 4th edition, December 8-9, 2016, Pro Universitaria Publishing House, Bucharest, Romania (2017)

[27] BERRY DAVID, The Romanian Mass Media and Cultural Development, Routledge publishing house, New York (2017) 